\title{
Progesterone Blockade of Estrogen Activation of $\mu$-Opioid Receptors Regulates Reproductive Behavior
}

\author{
Kevin Sinchak and Paul E Micevych \\ Department of Neurobiology, Mental Retardation Research Center and Laboratory of Neuroendocrinology, Brain \\ Research Institute, University of California, Los Angeles, School of Medicine, Los Angeles, California 90095-1763
}

The $\mu$-opioid receptor (MOR), a G-protein-coupled receptor, is internalized after endogenous agonist binding. Although receptor activation and internalization are separate events, internalization is a good assay for activation because endogenous opioid peptides all induce internalization. Estrogen treatment of ovariectomized rats induces MOR internalization, providing a neurochemical signature of estrogen activation of the medial preoptic nucleus. MOR activation appears to be the mechanism via which estrogen acts in the medial preoptic area to prevent the display of female reproductive behavior during the first 20-24 hr after estrogen treatment. Naltrexone, an alkaloid universal opioid receptor antagonist, prevented MOR internalization, suggesting that estrogen induces the release of endogenous opioid peptides that in turn activate the MOR. Enkephalins and $\beta$-endorphin are nonselective endogenous MOR ligands. The most selective endogenous MOR ligands are the endomorphins. Infusions of selective MOR agonists,
H-Tyr-D-Ala-Gly-N-Met-Phe-glycinol-enkephalin (DAMGO) or endomorphin-1, into the medial preoptic nucleus attenuated lordosis, and their effects were blocked with the MOR antagonist $H$-D-Phe-Cys-Tyr-D-Trp-Orn-Thr-Pen-Thr-NH $\mathrm{NH}_{2}$ (CTOP). Infusion of endomorphin-1 internalized MOR. To determine whether progestin also acts via the MOR system to facilitate reproductive behavior, ovariectomized rats were primed with $17 \beta$-estradiol and progesterone. Progestin facilitation of lordosis was correlated with a reduction of estrogen-induced MOR internalization. Progestin reversed estrogen-induced MOR internalization, suggesting that progesterone blocked estrogeninduced endogenous opioid release, relieving estrogen inhibition and facilitating lordosis. These results indicate a central role of MOR in the mediation of sex steroid activation of the CNS to regulate female reproductive behavior.

Key words: sexual receptivity; CTOP; DAMGO; endomorphin-1; G-protein-coupled receptors; medial preoptic nucleus
A fundamental question in neuroendocrinology is how hormonal information is transduced by neural circuitry to regulate reproduction. Estrogens and progestins act via receptors within interconnected limbic system and hypothalamic circuits that modulate the display of female sexual behavior (lordosis). Endogenous opioid peptides are important intercellular messengers in these circuits. Endogenous opioid peptides activate specific receptors within the limbic-hypothalamic lordosis-regulating circuits to mediate facilitatory and inhibitory effects of sex steroids.

$\mu$-Opioid receptors (MOR), typical G-protein-coupled receptors with seven membrane passes, are translocated from the plasma membrane to endosomes after endogenous opioid peptide stimulation. This G-protein-coupled receptor internalization is a signature of receptor activation in response to a stimulus (Allen et al., 1997; Micevych et al., 1997; Trafton et al., 2000). Estrogen induces MOR internalization in the medial preoptic nucleus (MPN) and the posterodorsal medial amygdaloid nucleus (Eckersell et al., 1998). Estrogen-induced MOR internalization is dependent on ligand-receptor binding. Naltrexone, a universal alkaloid opioid antagonist, prevented estrogen-induced MOR

Received Jan. 5, 2001; revised April 18, 2001; accepted May 9, 2001.

This work was supported by National Institutes of Health Grants NS39495 and DA13185. We thank Drs. C. J. Evans and N. T. Maidment and Jeff Fein of the Hatos Research Center (University of California, Los Angeles) for their generous gifts of peptide and use of behavioral rooms; Janelle Asai, Mary Kay Lobo, Oge Ilozue, Diana Katzman, Raz Khavari, and Veronica Quezada for technical support; and Drs. Paul Popper and Richard Mills for their comments.

Correspondence should be addressed to Dr. Kevin Sinchak, Department of Neurobiology, University of California, Los Angeles, Los Angeles, CA 90095-1763. E-mail: sinchak@mednet.ucla.edu.

Copyright () 2001 Society for Neuroscience $0270-6474 / 01 / 215723-07 \$ 15.00 / 0$ internalization, suggesting that estrogen releases endogenous opioid peptides that bind to MOR, stimulating internalization. MOR, like most opioid receptors, has several endogenous ligands, including $\beta$-endorphin, enkephalins, and recently characterized MOR-selective endomorphins (Patterson et al., 1983; Smith et al., 1983; Goldstein and Naidu, 1989; Zadina et al., 1997). Distribution studies suggest that endomorphin-1 (ENDO-1) is a likely MOR ligand in the MPN (Martin-Schild et al., 1999; Pierce and Wessendorf, 2000).

Although estrogen eventually induces lordosis, this effect is delayed. Immediately after estrogen treatment, females are not sexually receptive (Beach, 1948). This delay has been attributed to estrogen-induced transcription and translation; however, lordosis may be also prevented by inhibitory mechanisms activated by estrogen. For example, estrogen decreases neuronal firing in the medial preoptic area (Kow et al., 1994). Because MOR agonists infused into the medial preoptic area inhibit lordosis (Wiesner and Moss, 1984, 1986; Sirinathsinghji, 1986), estrogeninduced internalization of MOR immunoreactivity (MORi) in MPN circuits may be neurochemical correlates of estrogeninduced inhibition of neuronal firing and lordosis.

Initially estrogen increases progestin receptor expression through which progestins act to facilitate lordosis (Edwards et al., 1968; MacLusky and McEwen, 1978, 1980; Parsons et al., 1980; Romano et al., 1989; Hagihara et al., 1992; Simerly et al., 1996; Shughrue et al., 1997). However, the downstream neurochemical events induced by progestin to facilitate lordosis remain uncharacterized. Progestin facilitates lordosis in estrogen-primed nonreceptive females, suggesting that progestin interrupts estrogen- 
mediated inhibition of lordosis in the MPN. Because MOR activation inhibits lordosis, progestin blockade of endogenous MOR peptide release would relieve MOR inhibition and facilitate lordosis.

In the present study, progestin induction of lordosis in nonreceptive female rats treated with estrogen was correlated with MORi internalization, as a measure of receptor activation. Second, MOR agonists and antagonists were infused into the MPN to study the role of MOR in the estrogen + progestin regulation of lordosis. Finally, we correlated ENDO-1 inhibition of lordosis and MORi internalization, demonstrating that MOR-selective endogenous peptide activation in the MPN regulates lordosis.

Parts of this paper have been published previously (Sinchak et al., 1999).

\section{MATERIALS AND METHODS}

Subjects. Male and ovariectomized (OVX) female (250 gm) Long-Evans rats were purchased from Harlan Sprague Dawley (Indianapolis, IN). Females were bilaterally OVX while anesthetized with halothane (2-3\% in equal parts oxygen and nitrous oxide) by the distributor. All rats were housed two per cage in a partially reversed $12 / 12 \mathrm{hr}$ light/dark cycle (lights on at 12 midnight) and provided food and water ad libitum except during behavioral testing. All of the procedures were approved by the Chancellor's Animal Research Committee at the University of California, Los Angeles.

Implantation surgery of guide cannulas. For the behavioral experiments, 2 weeks after OVX surgery, rats were implanted with bilateral guide cannulas (24 ga) directed at the MPN (coordinates from bregma, anterior, $-0.1 \mathrm{~mm}$; lateral, $\pm 0.8 \mathrm{~mm}$; and ventral, $-6.0 \mathrm{~mm}$ from dura; tooth bar, $-3.3 \mathrm{~mm}$ ) using standard stereotaxic procedures while anesthetized with halothane (2-3\% in equal parts oxygen and nitrous oxide). The cannulas were secured to the skull with dental cement and bone screws. Stylets were placed in the guide cannulas that protruded $<0.5 \mathrm{~mm}$ beyond the opening of the cannulas. Animals were allowed to recover $7 \mathrm{~d}$ before behavioral testing.

Microinjection. For each experiment, drugs were dissolved in artificial CSF (aCSF) vehicle (Babcock et al., 1988). In the behavioral experiments, solutions were injected using an infusion pump (Harvard Instruments) at a rate of $0.5 \mu \mathrm{l} / \mathrm{min}$ (total volume of $0.5 \mu \mathrm{l}$ per side). The microinjection needle protruded $2 \mathrm{~mm}$ past the opening of the cannulas and remained in the cannulas $\sim 1 \mathrm{~min}$ after injection to allow for diffusion of drug or aCSF from the injector. After microinjection, stylets were reinserted into the guide cannulas, and the animals were returned to their home cage until the time of testing.

Steroid priming and behavioral test design. Steroids were dissolved in safflower oil vehicle and injected subcutaneously in a total volume of 0.1 $\mathrm{ml}$. In all experiments, OVX rats were primed with $2 \mu \mathrm{g}$ of estradiol benzoate (EB) every fourth day for three cycles. This paradigm was chosen to mimic the natural-occurring pattern and level of estrogen in the intact female rat (Micevych et al., 1994). In experiment I, the time course of progestin facilitation of sexual receptivity in OVX rats primed with $2 \mu \mathrm{g}$ of EB was determined. Progesterone $(500 \mu \mathrm{g})$ was administered $8,12,16,19,26,32$, or $56 \mathrm{hr}$ after EB, or oil vehicle was administered 8 or $26 \mathrm{hr}$ after EB; rats were tested for sexual receptivity $4 \mathrm{hr}$ after oil vehicle or progesterone treatment. Progesterone and oil vehicle injections were given $1 \mathrm{hr}$ before the dark phase of the cycle.

Based on the results from Eckersell et al. (1998) and experiment I, experiment II determined whether progesterone treatment that facilitates sexual receptivity in EB-treated OVX rats decreases the activity of MOR circuits in the MPN. OVX rats were treated once every $4 \mathrm{~d}$ with $2 \mu \mathrm{g}$ of EB for three cycles. Twenty-six hours after the third EB treatment, either $500 \mu \mathrm{g}$ of progesterone or oil vehicle was injected, and $4 \mathrm{hr}$ later animals were killed and prepared for immunocytochemistry.

Experiments III and IV tested whether site-specific activation of the MOR system in the MPO inhibited sexual receptivity. Four days after guide cannulas were implanted, each female received sequential injections of $2 \mu \mathrm{g}$ of EB $3 \mathrm{hr}$ before dark phase and $500 \mu \mathrm{g}$ of progesterone $26 \mathrm{hr}$ later. This treatment was repeated every fourth day. Behavioral testing began $30 \mathrm{hr}$ after injection of $\mathrm{EB}, 3 \mathrm{hr}$ into the dark phase of the light cycle. Female rats were tested for sexual receptivity during the second steroid treatment cycle after cannulation surgery to confirm responsiveness to steroids. On the third $\mathrm{EB}+$ progesterone treatment cycle after implantation of cannulas in experiment III, females received bilateral microinjections of 1,5 , or $25 \mathrm{nmol}$ of ENDO- 1 (dissolved in 0.5 $\mu \mathrm{l}$ of aCSF per side) or aCSF $\sim 30 \mathrm{hr}$ after EB. Each rat was tested for sexual receptivity 10 and $60 \mathrm{~min}$ after microinjection. In experiment IV, females received two sets of bilateral infusions. The first infusion was either the MOR antagonist H-D-Phe-Cys-Tyr-D-Trp-Orn-Thr-Pen-Thr$\mathrm{NH}_{2}$ (CTOP; $\left.25 \mathrm{nmol}\right)$ or aCSF vehicle. Ten minutes later, the second bilateral infusion contained either $H$-Tyr-D-Ala-Gly- $N$-Met-Pheglycinol-enkephalin (DAMGO; $0.2 \mathrm{nmol}$ ), ENDO-1 (25 nmol), or aCSF. Animals were tested for lordosis $10 \mathrm{~min}$ after the second microinfusion.

To measure sexual receptivity, each female was placed in a Plexiglas testing arena with a male (males were acclimatized to the arenas for 30 min before testing). The male was allowed to mount the female vigorously 10 times. The number of times that the female displayed lordosis (lifting of the head, arching of the back, and movement of the tail to one side) when mounted by a male was recorded. For each female, a lordosis quotient (LQ) was calculated (number of lordosis displays/number of mounts $\times 100)$ as a measure of sexual receptivity. In experiments I and IV, LQ data were transformed using an arcsine square root transformation and analyzed by one-way ANOVA and Student-Newman-Keuls post hoc (SNK). In experiment III, LQ data were transformed using an arcsine square root transformation and analyzed by two-way ANOVA and SNK post hoc analysis. In all cases $p<0.05$ were considered significant.

Confirmation of the placement of guide cannulas. At the end of the behavioral series, animals were anesthetized with sodium pentobarbital $(50 \mathrm{mg} / \mathrm{kg})$ and decapitated. Brains were removed, blocked, and quickly frozen with powdered dry ice in OTC embedding media (Fisher Scientific, Houston, TX). Brains were stored at $-20^{\circ} \mathrm{C}$ and sectioned in a cryostat (Zeiss Microm). Twenty-five micrometer sections were melted onto Superfrost Plus slides (Fisher Scientific), stained with thionin, dehydrated, and coverslipped with Permount mounting medium (Fisher Scientific). Injection sites were verified under bright-field illumination.

MOR immunocytochemistry. In experiment II, $30 \mathrm{hr}$ after the final EB treatment and $4 \mathrm{hr}$ after the final progesterone or oil vehicle treatment, each animal was deeply anesthetized with sodium pentobarbital (50 $\mathrm{mg} / \mathrm{kg}$ ) and perfused transcardially with chilled physiological saline followed by $4 \%$ paraformaldehyde in Sorensen's buffer. Brains were removed and post-fixed in paraformaldehyde overnight and cryoprotected in $15 \%$ sucrose-phosphate buffer. Twenty micrometer sections through the MPN were obtained with a cryostat.

To determine whether ENDO-1 activates MOR (Experiment V), ENDO-1 was microinf used into the lateral ventricle of EB-treated OVX rats. Under halothane anesthesia and by the use of standard stereotaxic procedures, a 25 ga cannula aimed just above the lateral ventricle (coordinates from bregma, posterior, $1.0 \mathrm{~mm}$; lateral, $1.4 \mathrm{~mm}$; and ventral from skull, $-3.5 \mathrm{~mm}$ ) was implanted and secured to the skull with bone screws and dental acrylic. A stylet was inserted in the cannula. This stylet was checked and cleaned daily to maintain patency of the cannula. The rats were allowed to recover 1 week before infusion treatment. ENDO-1 $(50 \mathrm{nmol})$ was infused into the lateral ventricle via a 30 ga injector that protruded $2 \mathrm{~mm}$ beyond the opening of the cannula. The injector remained in place for $1 \mathrm{~min}$ after completion of the infusion. Ten minutes after the infusion, each animal was deeply anesthetized $(50 \mathrm{mg} / \mathrm{kg}$ sodium pentobarbital), perfused, and prepared for MOR immunocytochemistry as described above.

MOR immunocytochemistry, modified from Eckersell et al. (1998), used an affinity-purified antibody $\left(\mathrm{MOR}_{387-398}\right.$; gift from C. Evans and B. Anton, University of California, Los Angeles) raised in rabbits against a synthetic fragment (LENLEAETAPLP) corresponding to the intracellular $\mathrm{C}$ terminal of rat MOR. Free-floating tissue sections were washed in PBS followed by incubation in $1 \%$ normal goat serum, $1 \%$ bovine serum albumin, and $0.3 \%$ Triton X-100 in PBS for 30 min. Sections were then incubated for $48 \mathrm{hr}$ with the affinity-purified MOR antibody at $4^{\circ} \mathrm{C}$. Primary antibody dilutions were 1:5000 for fluorescence and 1:2000 for 3,3'-diaminobenzidine tetrahydrochloride (DAB) in PBS with $1 \%$ normal goat serum, $1 \%$ bovine serum albumin, and $0.3 \%$ Triton $\mathrm{X}-100$. After $48 \mathrm{hr}$, sections were washed in $0.1 \mathrm{M}$ Tris buffer, and alternate sections were processed with an avidin-biotin-peroxidase complex and either a fluorescent label for laser-scanning confocal microscopy or the chromogen DAB for light microscopy.

Sections processed for fluorescence were incubated in blocking buffer (Tyramide Signal Amplification kit; NEN Life Science Products, Boston, MA) and then in biotin-conjugated goat anti-rabbit IgG (1:200; Vector Laboratories, Burlingame, CA) for $1 \mathrm{hr}$. Tissue was then washed in 


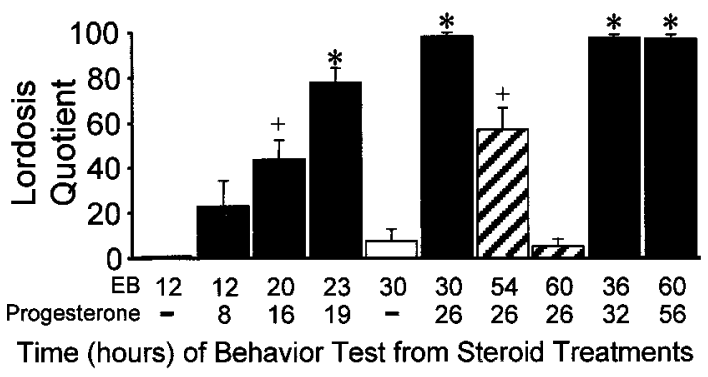

Figure 1. Time course of responsiveness of estrogen-treated females to progesterone facilitation of sexual receptivity as measured by lordosis quotient. Females were tested at various times after $2 \mu \mathrm{g}$ of EB and 500 $\mu \mathrm{g}$ of progesterone or $4 \mathrm{hr}$ after oil vehicle (-) treatment. Similar symbols $(+, *)$ signify equivalent groups within the $\mathrm{EB}+$ progesterone-treated groups only (SNK $p<0.05)$. EB + oil vehicle and $\mathrm{EB}+$ progesterone groups of females were not compared statistically.

Tris-buffered saline, incubated in streptavidin-horseradish peroxidase (1:100; NEN Life Science Products) for $30 \mathrm{~min}$, washed, and then incubated for $5 \mathrm{~min}$ in Fluorescein-conjugated tyramide (1:50; Tyramide Signal Amplification kit; NEN Life Science Products). Sections were again washed in $0.1 \mathrm{M}$ Tris buffer and mounted on Superfrost Plus slides (Fisher Scientific). Mounted sections were air dried and coverslipped using Vectashield mounting medium (Vector Laboratories).

Sections processed for bright-field microscopy were incubated with biotinylated goat anti-rabbit $\operatorname{IgG}(1: 200 ; 1 \mathrm{hr})$ followed by an avidinbiotin complex coupled to horseradish peroxidase $(1: 50 ; 1 \mathrm{hr}$; Vectastain Elite; Vector Laboratories) and visualized with the chromogen DAB (Sigma, St. Louis, MO). Sections were mounted on Superfrost Plus slides, processed through a series of graded alcohols and xylene, and coverslipped with Permount mounting medium (Fisher Scientific). To minimize variability, tissue from each treatment group was processed together.

Analysis. A Zeiss LSM 410 laser-scanning confocal microscope system (Zeiss, Thornwood, NY) was used to visualize the subcellular distribution of MORi. The excitation source was a krypton-argon laser (Coherent, Santa Clara, CA) with output at 488, 568, and $633 \mathrm{~nm}$. Fluorescein was imaged with a $488 \mathrm{~nm}$ emission filter and a 515-540 $\mathrm{nm}$ bandpass filter. Images were adjusted for brightness and contrast using the Zeiss LSM-PC program before printing with an Epson 1200 color printer. MORi was considered internalized when the majority of immunoreactivity was observed in the vesicles within the cytoplasm of neuronal cell bodies and processes (see Fig. 2). The density of labeled DAB MORi somata and processes was positively correlated with the level of MORi internalization visualized by confocal laser-scanning microscopy (Eckersell et al., 1998). The density of MORi processes as a measure of internalization was determined by superimposing a set of perpendicular lines onto images of the MPN at four to six levels throughout the rostrocaudal extent of the nucleus (see Fig. 3). All distinct, MORi processes that intersected or touched the line were counted, and the density was calculated by normalizing the number of processes to a 100 $\mu \mathrm{m}$ line length. The effects of steroid treatment in the MPN were compared using one-way ANOVA with SNK post hoc comparisons (Sigma Stat; Jandel Scientific, San Rafael, CA), and differences at the $p<0.05$ level were considered significant. The effects of ENDO-1 inf usion were compared using the $t$ test, and differences at the $p<0.05$ level were considered significant.

\section{RESULTS}

\section{Experiment I}

As reported previously, OVX rats treated with oil vehicle were uniformly sexually nonreceptive $(\mathrm{LQ} \sim 0)$. Likewise, a $2 \mu \mathrm{g}$ dose of EB did not facilitate lordosis at the 12 or $30 \mathrm{hr}$ time points after treatment (Fig. 1). The rats primed with $2 \mu \mathrm{g}$ of EB and given progesterone $4 \mathrm{hr}$ before testing were sexually receptive when tested at $20 \mathrm{hr}$ and maximally receptive at $23 \mathrm{hr}$ after EB treatment. Progesterone could not overcome the initial period of nonreceptivity at $12 \mathrm{hr}$ after EB. Estrogen priming was long-
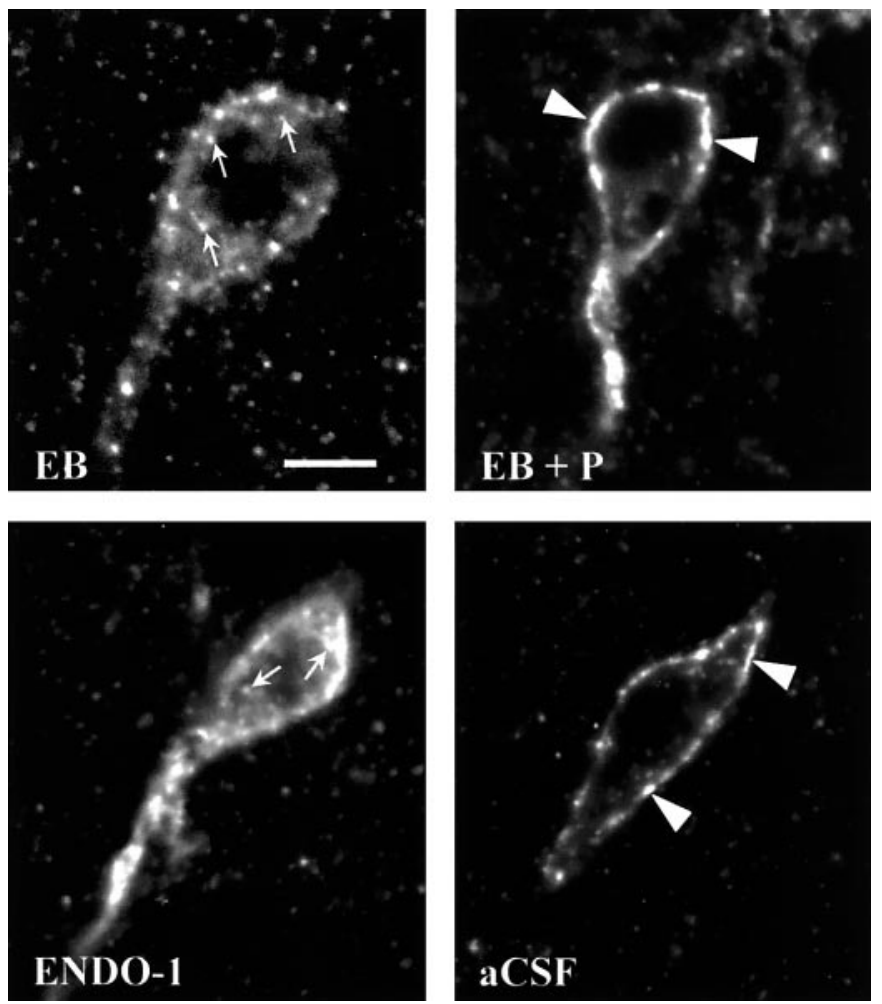

Figure 2. Confocal projections of MOR immunoreactivity in the MPN of ovariectomized rats that were treated with $2 \mu \mathrm{g}$ of estradiol benzoate followed by either oil vehicle $(E B)$ or $500 \mu \mathrm{g}$ of progesterone $(E B+P) 26$ hr later and were killed $30 \mathrm{hr}$ after the initial treatment (Experiment II) or received a microinfusion of either ENDO-1 $(50 \mathrm{nmol})$ or aCSF into the lateral ventricle (Experiment V). The resulting images illustrate that both EB- and ENDO-1-treated animals had an internalized pattern of MOR immunoreactivity (arrows). In $E B+P$ - and aCSF-treated rats, MOR immunoreactivity was associated with the plasma membrane (arrowheads), indicating that these receptors were not activated. Scale bar, $10 \mu \mathrm{m}$.

lasting. Sexual receptivity could be induced by progesterone $4 \mathrm{hr}$ before testing up to $60 \mathrm{hr}$ after EB priming (Fig. 1). In rats given progesterone $26 \mathrm{hr}$ after $\mathrm{EB}$, sexual receptivity began to wane 28 $\mathrm{hr}$ after progesterone treatment. By $34 \mathrm{hr}$ after progesterone treatment, females were not receptive (Fig. 1).

\section{Experiment II}

Previously, we had reported that $50 \mu \mathrm{g}$ of EB induced MOR internalization for at least $24 \mathrm{hr}$ (Eckersell et al., 1998). Now using a repeated priming schedule of $2 \mu \mathrm{g}$ of EB that mimicked the level and timing of estrogen surge during the estrous cycle, we demonstrate MOR internalization. It was also shown that the time course of internalization extended to $30 \mathrm{hr}$ after EB (Figs. 2, $3,4)$. In addition to increasing the number of distinct MORi processes in the MPN, EB treatment dramatically increased the number of varicose MORi processes compared with oil vehicletreated, control females. This increase in varicose processes is caused by a reduction in the plasma membrane because of massive internalization (Fig. 3) (Mantyh et al., 1995b; Allen et al., 1997). Progesterone treatment did not alter the distribution of MORi fibers throughout the medial preoptic area. However, progesterone injected $26 \mathrm{hr}$ after EB and $4 \mathrm{hr}$ before rats were killed (30 hr after EB) induced a pattern of cellular MORi distribution similar to that seen in the oil vehicle-treated OVX controls (Figs. 2, 3). With $\mathrm{EB}+$ progesterone treatment, the majority of MORi was associated with the plasma membrane, 

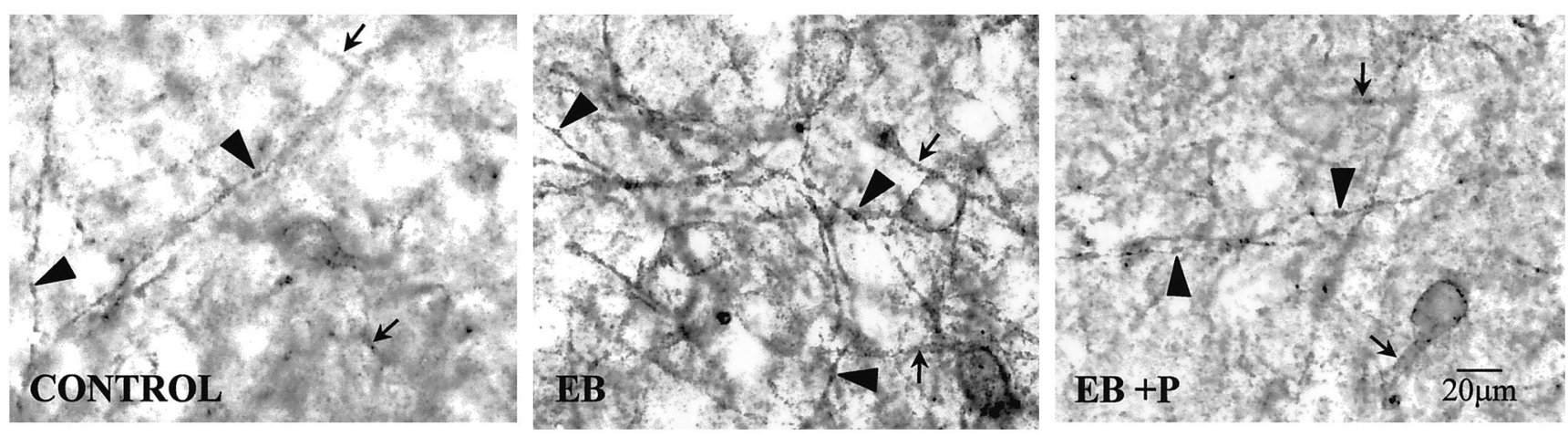

Figure 3. Bright-field photomicrographs of 3,3'-diaminobenzidine tetrahydrochloride-stained MOR immunoreactivity localization in the medial MPN dorsal to the central MPN in the region quantified in ovariectomized rats treated with $2 \mu \mathrm{g}$ of estradiol benzoate and either oil vehicle $(E B)$ or $500 \mu \mathrm{g}$ of progesterone $(E B+P) 26 \mathrm{hr}$ later or oil vehicle initially and oil vehicle $26 \mathrm{hr}$ later $(C O N T R O L)$ and killed $30 \mathrm{hr}$ after the initial injection. CONTROL rats had a lower density of distinct MOR-immunoreactive processes compared with EB-treated rats. Although the density of distinct processes was low in the CONTROL rats, distinct processes suggested that a basal, estrogen-independent internalization of MOR occurs. The $E B+P$-treated rats exhibited a reversal of the estrogen-induced increase in MOR-immunoreactive fiber density to CONTROL levels. Distinct varicose MOR-immunoreactive fibers (arrowheads) were increased in EB-treated rats compared with the levels in the CONTROL and EB $+P$ groups that had MOR immunoreactivity that was mainly diffuse (arrows).

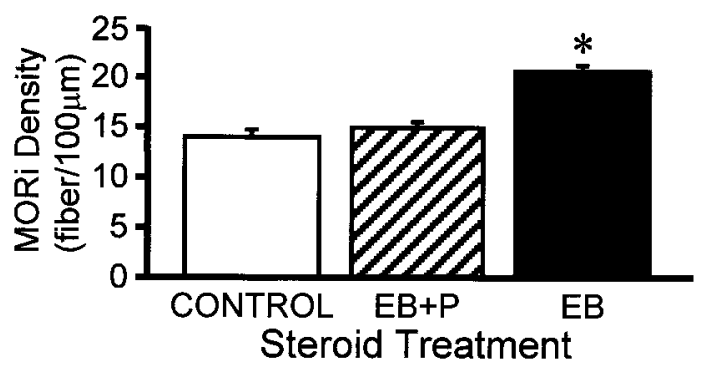

Figure 4. Effects of estrogen and progesterone treatment on the density of $\mu$-opioid receptor-immunoreactive (MORi) fibers stained with 3,3'diaminobenzidine tetrahydrochloride in the MPN. Ovariectomized rats were treated with $2 \mu \mathrm{g}$ of estradiol benzoate and either oil vehicle $(E B)$ or $500 \mu \mathrm{g}$ of progesterone $(E B+P) 26 \mathrm{hr}$ later or oil vehicle initially and 26 $\mathrm{hr}$ later oil vehicle (CONTROL) again. Animals were killed $4 \mathrm{hr}$ after the final injection and processed for MOR immunocytochemistry $\left(^{*}\right.$, significantly greater MOR-immunoreactive fiber density than was found with other treatment groups; $p<0.05$, SNK).

indicating that progesterone reversed EB-induced MOR internalization (Figs. 2, 3). Progesterone treatment significantly reduced the EB-induced MORi fiber density from $20.6 \pm 1.2$ to $14.9 \pm 0.5$ MORi fibers/100 $\mu \mathrm{m}$ (Figs. 3, 4). Fiber density in the EB + progesterone-treated females was not significantly different from oil vehicle-treated control females $(14.0 \pm 0.7$ MORi fibers/100 $\mu \mathrm{m}$; ANOVA, $p=0.0007$; df $=2,11 ; F=7.39)$.

\section{Experiments III and IV}

ENDO-1 inhibited lordosis in EB + progesterone-treated females in a dose-related manner compared with the aCSF control (Fig. 5; two-way ANOVA, $p=0.001 ; F=6.15$; df $=3$, 69). ENDO-1 at 1 nmol did not inhibit sexual receptivity, whereas 5 and $25 \mathrm{nmol}$ doses significantly reduced LQ 10 min after treatment (SNK, $p<0.05$ ). ENDO-1 inhibition of lordosis was undetectable after $1 \mathrm{hr}(\mathrm{SNK}, p>0.05)$. Bilateral infusion of DAMGO (0.2 nmol) aimed at the MPN inhibited lordosis compared with aCSF control animals (Fig. 6; SNK, $p<0.05$; one-way ANOVA, $p<0.0001 ; F=67.9$; df $=2,28)$. Infusion of the MOR antagonist, CTOP, before either ENDO-1 or DAMGO blocked the inhibitory effects on lordosis (Figs. 6, 7; SNK, $p<0.05$ ). No gross motor deficits were noted with the doses of ENDO-1 used.

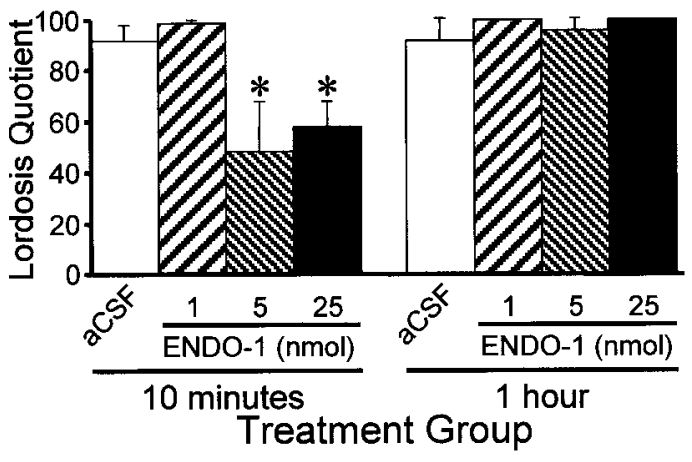

Figure 5. Effects of bilateral ENDO-1 (1, 5, $25 \mathrm{nmol} / \mathrm{side})$ or aCSF microinjections $(0.5 \mu \mathrm{l}$ of total volume/side) into the medial preoptic area on the lordosis quotient 10 and $60 \mathrm{~min}$ after microinjection. Ovariectomized rats were maximally receptive after sequential treatment with $2 \mu \mathrm{g}$ of $\mathrm{EB}+500 \mu \mathrm{g}$ of progesterone $26 \mathrm{hr}$ after EB. Animals were tested 30 hr after EB treatment. Values are means \pm SEM (*, significantly less than $\mathrm{aCSF}$ and $1 \mathrm{nmol}$ treatments at $10 \mathrm{~min}$ and less than within group treatments in the $60 \mathrm{~min}$ test; $p<0.05, \mathrm{SNK})$.

Low-dose DAMGO females exhibited typical hopping and darting, but mounts by the male did not elicit lordosis (Fig. 6). However, a higher dose $(2.4 \mathrm{nmol})$ of DAMGO produced a reduction of exploratory behavior and proceptive behavior (hopping and darting) in estrogen + progesterone-primed sexually receptive females. Animals with DAMGO-induced locomotor deficits were not receptive.

\section{Experiment V}

ENDO-1 has been suggested to be the endogenous MORselective agonist (Zadina et al., 1997). To test whether ENDO-1 would induce MOR internalization, ENDO-1 was infused into the lateral ventricle. Ten minutes after infusion of ENDO-1, at the time ENDO-1 inhibited lordosis, the majority of MORi was observed in varicose processes. Confocal examination revealed that the majority of MORi was not associated with the plasma membrane (Fig. 2). This pattern of MORi has been correlated with receptor internalization. In contrast, after intracerebroventricular infusion of aCSF, MORi was observed in larger diameter processes associated with the plasma membrane, indicating a lack of MOR internalization (Fig. 2). Quantification of MORi fiber 


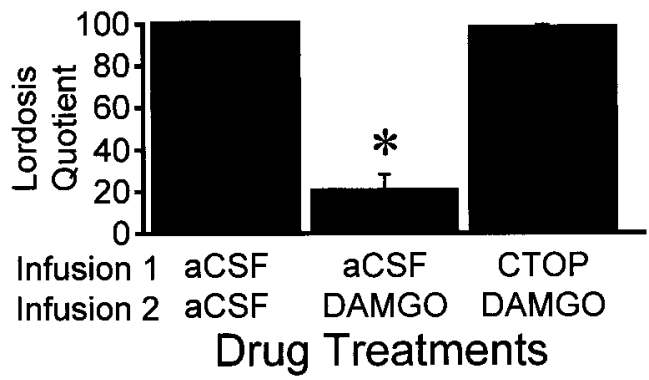

Figure 6. Effects of bilateral infusions of either the MOR-specific antagonist CTOP ( $25 \mathrm{nmol} / 0.5 \mu \mathrm{l}$ volume) or aCSF $10 \mathrm{~min}$ before bilateral infusion of the MOR-specific agonist DAMGO $(0.2 \mathrm{nmol} / 0.5 \mu \mathrm{l}$ volume $)$ into the medial preoptic area on lordosis quotient $10 \mathrm{~min}$ after the last injection. Ovariectomized rats were maximally receptive after treatment with $2 \mu \mathrm{g}$ of EB $+500 \mu \mathrm{g}$ of progesterone $26 \mathrm{hr}$ after EB. Animals were tested $30 \mathrm{hr}$ after EB treatment. Values are means \pm SEM ( ${ }^{*}$, significantly less than all other treatments; $p<0.05$, SNK).

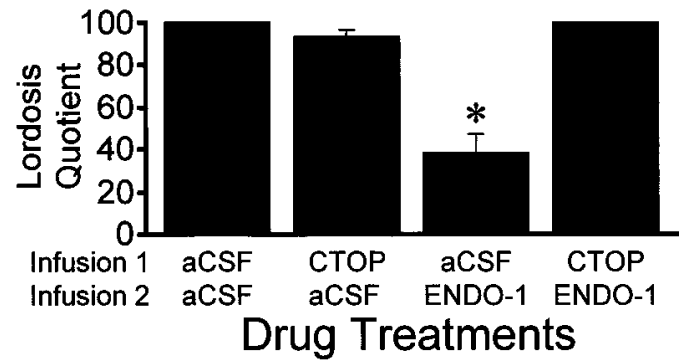

Figure 7. Effects of bilateral infusions of either the MOR-specific antagonist CTOP ( $25 \mathrm{nmol} / 0.5 \mu$ l volume) or aCSF $10 \mathrm{~min}$ before bilateral infusion of ENDO-1 (25 nmol/0.5 $\mu$ l volume) or aCSF on lordosis quotient $10 \mathrm{~min}$ after the last injection. Ovariectomized rats were maximally receptive after sequential treatment with $2 \mu \mathrm{g}$ of EB $+500 \mu \mathrm{g}$ of progesterone $26 \mathrm{hr}$ after EB. Animals were tested $30 \mathrm{hr}$ after EB treatment. Values are means \pm SEM (*, significantly less than all other treatments; $p<0.05, \mathrm{SNK}$ ).

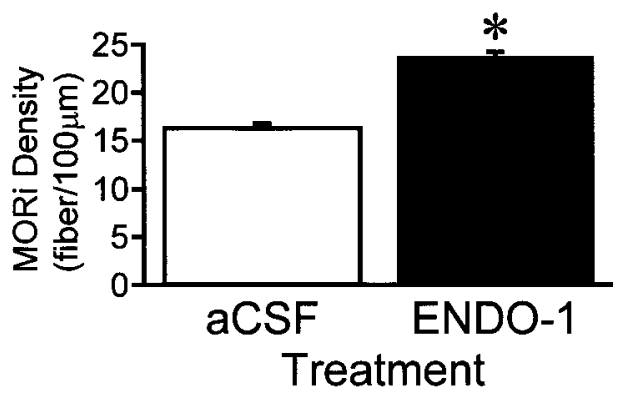

Figure 8. MORi fiber density in the MPN of ovariectomized rats that received either ENDO-1 $(50 \mathrm{nmol})$ or aCSF microinfusion into the lateral ventricle $(*$, significantly higher density of MOR-immunoreactive fibers compared with that in aCSF animals; $p<0.001)$. Each value is the mean $\pm \operatorname{SEM}(n=3$; df $=4)$.

density paralleled the confocal results. Fiber density increased from 16.3 \pm 0.5 MORi fibers/100 $\mu \mathrm{m}(\mathrm{aCSF})$ to $23.7 \pm 0.4 \mathrm{MORi}$ fibers $/ 100 \mu \mathrm{m}$ (ENDO-1; Fig. 8; $t$ test, $t=11.3$; df $=4 ; p=$ $0.0003)$.

\section{DISCUSSION}

The major finding of the present studies is that MOR internalization correlates with behavioral measures ascribed to MOR activation in the MPN. MOR activation inhibits lordosis (Pfaus et al., 1986; Sirinathsinghji, 1986; Pfaus and Gorzalka, 1987a,b; Pfaus and Pfaff, 1992). In the present study, estrogen or exogenous MOR agonists inhibited lordosis and produced dramatic MORi internalization (Figs. 2, 3), suggesting that the lack of sexual receptivity immediately after estrogen treatment (Fig. 1) is caused by MOR activation/internalization (Figs. 2, 3). In nonreceptive, estrogen-primed rats (Fig. 1), progesterone induced lordosis and reversed estrogen-induced MORi internalization, demonstrating that a pivotal action of progestin was to reverse the estrogen-induced MOR activation in the MPN. MOR activation inhibits lordosis, and blockade of MOR activation facilitates lordosis. We also showed that the selective endogenous MOR agonist, ENDO-1, inhibited lordosis and induced MORi internalization, demonstrating that specific activation of MOR correlated with its internalization and inhibition of lordosis.

This study expands our previous findings that MOR trafficking in the limbic-hypothalamic lordosis-regulating circuit was influenced by a natural stimulus, estrogen (Eckersell et al., 1998). The present study demonstrates that a physiological dose of $17 \beta$ estradiol, $2 \mu \mathrm{g}$, is sufficient to induce MOR internalization and that progesterone reverses the internalization, removing MOR inhibition and permitting lordosis. Our hypothesis is that estrogen acts on neurons that are presynaptic to the MOR to augment the release of endogenous opioid peptide(s) that selectively activates MOR, inhibiting lordosis. Progestin reverses estrogeninduced release of MOR endogenous peptide(s) and removes the opioid inhibition, allowing lordosis. Within the context of our experiment, in OVX rats, estrogen simultaneously increases the release of endogenous MOR-activating peptide(s) and induces progestin receptors. Progestin then acts on estrogen-induced progestin receptors to attenuate release of endogenous MORactivating peptide(s) and relieves MPN inhibition. This hypothesis of progestin action is supported by the ability of exogenous MOR agonists infused into the medial preoptic area to inhibit lordosis in estrogen + progestin-primed rats, indicating that the progestin-induced reduction in MOR action is not caused by a lack of sufficient MOR. Although a high dose of estrogen will induce lordosis, the onset of sexual receptivity does not occur until the second day after the initial exposure. Coincident with estrogen-induced sexual receptivity is a reduction in MOR activation in the MPN and medial amygdala, indicating that lordosis is facilitated after MOR activation is reduced (Eckersell et al., 1998). Our data suggest that the reduction of MOR activity is associated with reduced endogenous opioid peptide(s) release because MOR agonists will block estrogen-induced lordosis (K. Sinchak and P. E Micevych, unpublished data) (but see Pfaus and Pfaff, 1992). This experiment demonstrates specific neurochemical events that are correlated with estrogen + progestin facilitation of lordosis.

Although regulation of MOR activation is involved in neural regulation of lordosis, other cellular events are mediated by estrogen and progestin to facilitate this behavior. Estrogen upregulates a number of neurotransmitter and receptor systems in the medial preoptic area and ventromedial nucleus of the hypothalamus (Pfaff et al., 1994; Eckersell and Micevych, 1997). However, opioid circuit regulation appears to be a key to modulating lordosis. Estrogen increases mRNA expression of enkephalins (endogenous $\delta$-opioid receptor peptides) (Romano et al., 1988; Priest et al., 1995) that are thought to be responsible for facilitating lordosis, and progestin extends their increased expression. Moreover, estrogen increased expression of the orphanin FQ/ nociceptin receptor in the ventromedial nucleus of the hypothal- 
amus, and infusion of orphanin FQ/nociceptin into this region facilitated lordosis (Sinchak et al., 1997). Nevertheless, MOR activation is integral for the display of lordosis. Although MOR activation acutely inhibits sexual receptivity, when the initial estrogen-induced activation of MOR circuits is blocked, the resulting lordosis $48 \mathrm{hr}$ later is attenuated (Torii and Kubo, 1994; Torii et al., 1995, 1996, 1997). This suggests that rapid and prolonged activation of MOR by estrogen, although inhibitory to lordosis, is an important component of the sequence of estrogeninduced events needed to facilitate lordosis. The present results show that MOR activation and suppression of activation are part of the mechanism through which estrogen and progestin act to facilitate lordosis.

The present experiments specifically examined the actions of ENDO-1 on lordosis in the MPN. ENDO-1 is concentrated in the medial preoptic area (Zadina et al., 1997) and overlaps with MORi (Micevych et al., 1997; Eckersell et al., 1998; Martin-Schild et al., 1999). Results from the present study demonstrated that ENDO-1 is a viable endogenous opioid peptide candidate to activate MOR in the MPN in vivo and regulate lordosis. Like estrogen and etorphine (Eckersell et al., 1998), ENDO-1 internalized MORi in the MPN. This internalization parallels the effects of endogenous opioid peptides binding to MOR and other opioid receptors (Von Zastrow et al., 1993; Keith et al., 1998). G-protein-coupled receptor internalization is a general phenomenon and is part of the desensitization process that follows agonist binding (Mantyh et al., 1995b; Allen et al., 1997; Micevych et al., 1997; Trafton et al., 2000). Internalization can be visualized as a translocation of receptor immunoreactivity from the plasma membrane to endosomes at the electron microscopic level (Dournaud et al., 1998) or the confocal microscopic level (Mantyh et al., 1995a). Receptor internalization has been positively correlated with the density of DAB-stained MORi processes (Eckersell et al., 1998), whereas the nonactivated receptors were associated with the plasma membrane and had diffuse immunocytochemical staining (Dournaud et al., 1998; Eckersell et al., 1998). In the present study, we saw a similar increase in MORi fiber density that was associated with internalization of MORi visualized by confocal microscopy in the MPN when ENDO-1 was infused into the lateral ventricle (Figs. 7, 8). The time course of ENDO-1-induced MORi internalization (activation) correlated with ENDO-1 inhibition of lordosis by direct infusion into the MPN. Ten minutes after infusion, both inhibition of sexual receptivity and MORi internalization occurred (Figs. 2, 5). This rapid activation of MOR circuits was similar to that seen previously with estrogen or etorphine treatment (Eckersell et al., 1998).

The ENDO-1 inhibition of lordosis was less robust than with DAMGO. A 100-fold excess of ENDO-1 was not able to match the DAMGO inhibition of lordosis (Fig. 6). One reason may involve differences in signal transduction after DAMGO or ENDO-1 binding to MOR. For example, in an assay of functional coupling using $\left[{ }^{35} \mathrm{~S}\right] \mathrm{GTP} \gamma \mathrm{S}$ binding, ENDO-1 is a partial agonist, whereas DAMGO is a full agonist (Hosohata et al., 1998; Narita et al., 1998; Sim et al., 1998). In assays of MOR activation, however, ENDO-1 is a full agonist, inhibiting the cAMP-adenylyl cyclase pathway and activating G-protein-activated inward-rectifying potassium channels (Gong et al., 1998). In the present experiment, another explanation for the difference between DAMGO and ENDO-1 may be that endogenous peptidases quickly degrade ENDO-1 in the extracellular space and reduce its effective concentration, whereas DAMGO is more resistant to degradation.
Although ENDO-1 has high affinity and selectivity for MOR, other endogenous opioid peptides that activate MOR are present in the MPN. Both $\beta$-endorphin and enkephalins are located in the MPN (Khachaturian et al., 1985; Simerly et al., 1988) and exhibit steroid regulation (Hammer and Cheung, 1995; Holland et al., 1998). In particular, several lines of evidence suggest that estrogen also acts via $\beta$-endorphin circuits that may represent another pathway for MOR activation. In the arcuate nucleus, the site of origin of $\beta$-endorphin fibers in the MPN, a percentage of $\beta$-endorphinergic neurons contains receptors for estrogen (Morrell et al., 1985; Jirikowski et al., 1986) and progestin (Fox et al., 1990). The $\beta$-endorphin fiber density within the MPN varies with hormone treatment and across the estrous cycle (Ge et al., 1993). Finally, infusion of $\beta$-endorphin antibodies into the MPN facilitated sexual receptivity in estrogen-primed females, demonstrating that estrogen-induced MOR activation initially inhibits lordosis (Sirinathsinghji, 1986). However, $\beta$-endorphin also activates $\delta$-opioid receptors that have been implicated in facilitating lordosis (Pfaus and Pfaff, 1992). The present studies implicate a MORselective endogenous opioid peptide, ENDO-1, that selectively activates MOR unlike $\beta$-endorphin. Thus, in the context of an hypothesis of dual opioid control of lordosis, inhibition is probably mediated by ENDO-1.

In summary, the present experiments demonstrated cellular events associated with the steroid regulation of lordosis. Estrogen activation of MOR circuits prevented lordosis. Progestin, via reversal of estrogen-induced internalization of MOR, facilitated lordosis. Our results are consistent with the idea that progesterone antagonizes estrogen actions, at the level of the MOR. We hypothesize that estrogen induced the release of and subsequent progestin treatment blocked the release of endogenous MOR ligand(s). Significantly, this study suggested that ENDO-1 is the endogenous opioid peptide that can specifically activate MOR in a time frame consistent with ENDO-1 inhibition of lordosis. The pattern of internalization with ENDO-1 in the MPN parallels that induced by estrogen (Eckersell et al., 1998). Thus, the present study shows a convergence of estrogen and progestin signals onto MPN-MOR circuits and reveals a neurochemical signature of estrogen + progestin activation of the CNS.

\section{REFERENCES}

Allen BJ, Rogers SD, Ghilardi JR, Menning PM, Kuskowski MA, Basbaum AI, Simone DA, Mantyh PW (1997) Noxious cutaneous thermal stimuli induce a graded release of endogenous substance $\mathrm{P}$ in the spinal cord: imaging peptide action in vivo. J Neurosci 17:5921-5927.

Babcock AM, Block GJ, Micevych PE (1988) Injections of cholecystokinin into the ventromedial hypothalamic nucleus inhibit lordosis behavior in the rat. Physiol Behav 43:195-199.

Beach F (1948) Hormones and behavior. New York: Hoeber.

Dournaud P, Boudin H, Schonbrunn A, Tannenbaum GS, Beaudet A (1998) Interrelationships between somatostatin sst2A receptors and somatostatin-containing axons in rat brain: evidence for regulation of cell surface receptors by endogenous somatostatin. J Neurosci 18:1056-1071.

Eckersell CB, Micevych PE (1997) Opiate receptors modulate estrogeninduced cholecystokinin and tachykinin but not enkephalin mRNA levels in the limbic system and hypothalamus. Neuroscience 80:473-485.

Eckersell CB, Popper P, Micevych PE (1998) Estrogen-induced alteration of $\mu$-opioid receptor immunoreactivity in the medial preoptic nucleus and medial amygdala. J Neurosci 18:3967-3976.

Edwards DA, Whalen RE, Nadler RD (1968) Induction of estrus: estrogen-progesterone interactions. Physiol Behav 3:29-33.

Fox SR, Harlan RE, Shivers BD, Pfaff DW (1990) Chemical characterization of neuroendocrine targets for progesterone in the female rat brain and pituitary. Neuroendocrinology 51:276-283.

Ge F, Hammer Jr RP, Tobet SA (1993) Ontogeny of Leu-enkephalin and beta-endorphin innervation of the area in male and female rats. Brain Res Dev Brain Res 73:273-281. 
Goldstein A, Naidu A (1989) Multiple opioid receptors: ligand selectivity profiles and binding site signatures. Mol Pharmacol 36:265-272.

Gong J, Strong JA, Zhang S, Yue X, DeHaven RN, Daubert JD, Cassel JA, Yu G, Mansson E, Yu L (1998) Endomorphins fully activate a cloned human mu opioid receptor. FEBS Lett 439:152-156.

Hagihara K, Hirata S, Osada T, Hirai M, Kato J (1992) Distribution of cells containing progesterone receptor mRNA in the female rat di- and telencephalon: an in situ hybridization study. Brain Res Mol Brain Res 14:239-249.

Hammer RP, Cheung S (1995) Sex steroid regulation of hypothalamic opioid function. In: Neurobiological effects of sex steroid hormones (Micevych PE, Hammer RP, eds), pp 143-159. New York: Cambridge UP.

Holland KL, Norby LA, Micevych PE (1998) Peripubertal ontogeny and estrogen stimulation of cholecystokinin and preproenkephalin mRNA in the rat hypothalamus and limbic system. J Comp Neurol 392:48-57.

Hosohata K, Burkey TH, Alfaro-Lopez J, Varga E, Hruby VJ, Roeske WR, Yamamura HI (1998) Endomorphin-1 and endomorphin-2 are partial agonists at the human mu-opioid receptor. Eur J Pharmacol 346:111-114

Jirikowski GF, Merchenthaler I, Rieger GE, Stumpf WE (1986) Estradiol target sites immunoreactive for beta-endorphin in the arcuate nucleus of rat and mouse hypothalamus. Neurosci Lett 65:121-126.

Keith DE, Anton B, Murray SR, Zaki PA, Chu PC, Lissin DV, Monteillet-Agius G, Stewart PL, Evans CJ, von Zastrow M (1998) $\mathrm{Mu}$-opioid receptor internalization: opiate drugs have differential effects on a conserved endocytic mechanism in vitro and in the mammalian brain. Mol Pharmacol 53:377-384.

Khachaturian H, Lewis ME, Schafer MK-H, Watson SJ (1985) Anatomy of the CNS opioid systems. Trends Neurosci 8:111-119.

Kow LM, Mobbs CV, Pfaff DW (1994) Roles of second-messenger systems and neuronal activity in the regulation of lordosis by neurotransmitters, neuropeptides, and estrogen: a review. Neurosci Biobehav Rev 18:251-268.

MacLusky NJ, McEwen BS (1978) Oestrogen modulates progestin receptor concentrations in some rat brain regions but not in others. Nature 274:276-278.

MacLusky NJ, McEwen BS (1980) Progestin receptors in the rat brain: distribution and properties of cytoplasmic progestin binding sites. Endocrinology 106:192-202.

Mantyh PW, Allen CJ, Ghilardi JR, Rogers SD, Mantyh CR, Liu H, Basbaum AI, Vigna SR, Maggio JE (1995a) Rapid endocytosis of a G protein-coupled receptor: substance $\mathrm{P}$ evoked internalization of its receptor in the rat striatum in vivo. Proc Natl Acad Sci USA 92:2622-2626.

Mantyh PW, DeMaster E, Malhotra A, Ghilardi JR, Rogers SD, Mantyh CR, Liu H, Basbaum AI, Vigna SR, Maggio JE, Simone DA (1995b) Receptor endocytosis and dendrite reshaping in spinal neurons after somatosensory stimulation. Science 268:1629-1632.

Martin-Schild S, Gerall AA, Kastin AJ, Zadina JE (1999) Differential distribution of endomorphin 1- and endomorphin 2-like immunoreactivities in the CNS of the rodent. J Comp Neurol 405:450-471.

Micevych PE, Abelson L, Fok H, Ulibarri C, Priest CA (1994) Gonadal steroid control of preproenkephalin mRNA expression in the limbichypothalamic circuit: comparison of adult with neonatal steroid treatments. J Neurosci Res 38:386-398.

Micevych PE, Eckersell CB, Brecha N, Holland K (1997) Estrogenic modulation of opiate and cholecystokinin systems in the limbichypothalamic circuit. Brain Res Bull 44:335-343.

Morrell JI, McGinty JF, Pfaff DW (1985) A subset of beta-endorphin- or dynorphin-containing neurons in the medial basal hypothalamus accumulates estradiol. Neuroendocrinology 41:417-426.

Narita M, Mizoguchi H, Oji GS, Tseng EL, Suganuma C, Nagase H, Tseng LF (1998) Characterization of endomorphin-1 and -2 on $\left.{ }^{35} \mathrm{~S}\right]$ GTP gamma S binding in the mouse spinal cord. Eur J Pharmacol 351:383-387.

Parsons B, MacLusky NJ, Krey L, Pfaff DW, McEwen BS (1980) The temporal relationship between estrogen-inducible progestin receptors in the female rat brain and the time course of estrogen activation of mating behavior. Endocrinology 107:774-779.

Patterson SJ, Robson LE, Kosterlitz HW (1983) Classification of opiate receptors. Br Med Bull 39:31-36.

Pfaff DW, Schwartz-Giblin S, McCarthy M, Kow LM (1994) Cellular and molecular mechanisms of female reproductive behaviors. In: The physiology of reproduction (Knobil E, Neill JD, eds), pp 107-220. New York: Raven.

Pfaus JG, Gorzalka BB (1987a) Opioids and sexual behavior. Neurosci Biobehav Rev 11:1-34
Pfaus JG, Gorzalka BB (1987b) Selective activation of opioid receptors differentially affects lordosis behavior in female rats. Peptides 8:309-317.

Pfaus JG, Pfaff DW (1992) $\mu$-, $\delta$-, and $\kappa$-opioid receptor agonists selectively modulate sexual behaviors in the female rat: differential dependence on progesterone. Horm Behav 26:457-473.

Pfaus JG, Pendleton N, Gorzalka BB (1986) Dual effect of morphiceptin on lordosis behavior: possible mediation by different opioid receptor subtypes. Pharmacol Biochem Behav 24:1461-1464.

Pierce TL, Wessendorf MW (2000) Immunocytochemical mapping of endomorphin-2-immunoreactivity in rat brain. J Chem Neuroanat 18:181-207.

Priest CA, Eckersell CB, Micevych PE (1995) Estrogen regulates preproenkephalin-A mRNA levels in the rat ventromedial nucleus: temporal and cellular aspects. Brain Res Mol Brain Res 28:251-262.

Romano GJ, Harlan RE, Shiverst BD, Howells RD, Pfaff DW (1988) Estrogen increases proenkephalin messenger ribonucleic acid levels in the ventromedial hypothalamus of the rat. Mol Endocrinol 2:1320-1328.

Romano GJ, Krust A, Pfaff DW (1989) Expression and estrogen regulation of progesterone receptor mRNA in neurons of the mediobasal hypothalamus: an in situ hybridization study. Mol Endocrinol [Erratum (1989) 3:1860] 3:1295-1300.

Shughrue PJ, Lane MV, Merchenthaler I (1997) Regulation of progesterone receptor messenger ribonucleic acid in the rat medial preoptic nucleus by estrogenic and antiestrogenic compounds: an in situ hybridization study. Endocrinology 138:5476-5484.

Sim LJ, Liu Q, Childers SR, Selley DE (1998) Endomorphin-stimulated $\left[{ }^{35} \mathrm{~S}\right]$ GTPgammaS binding in rat brain: evidence for partial agonist activity at mu-opioid receptors. J Neurochem 70:1567-1576.

Simerly RB, McCall LD, Watson SJ (1988) Distribution of opioid peptides in the preoptic region: immunohistochemical evidence for a steroid-sensitive enkephalin sexual dimorphism. J Comp Neurol 276:442-459.

Simerly RB, Carr AM, Zee MC, Lorang D (1996) Ovarian steroid regulation of estrogen and progesterone receptor messenger ribonucleic acid in the anteroventral periventricular nucleus of the rat. J Neuroendocrinol 8:45-56.

Sinchak K, Hendricks DG, Baroudi R, Micevych PE (1997) Orphanin $\mathrm{FQ} /$ nociceptin in the ventromedial nucleus facilitates lordosis in female rats. NeuroReport 8:3857-3860.

Sinchak K, Khavari R, Katzman D, Micevych PE (1999) Sexual receptivity is associated with a reduction in internalization of mu-opioid receptors in the medial preoptic nucleus in cycling and steroid primed ovariectomized rats. Soc Neurosci Abstr 25:1705.

Sirinathsinghji DJS (1986) Regulation of lordosis behavior in the female rat by corticotropin-releasing factor, beta-endorphin/corticotropin and luteinizing hormone-releasing hormone neuronal systems in the medial preoptic area. Brain Res 375:149-156.

Smith A, Lee N, Loh H (1983) The multiple-site beta-endorphin receptor. Trends Pharmacol Sci 4:163-164.

Torii M, Kubo K (1994) The effects of intraventricular injection of betaendorphin on initial estrogen action to induce lordosis behavior. Physiol Behav 55:157-162.

Torii M, Kubo K, Sasaki T (1995) Naloxone and initial estrogen action to induce lordosis in ovariectomized rats: the effect of a cut between the septum and preoptic area. Neurosci Lett 195:167-170.

Torii M, Kubo K, Sasaki T (1996) Influence of opioid peptides on the priming action of estrogen on lordosis in ovariectomized rats. Neurosci Lett 212:68-70.

Torii M, Kubo K, Sasaki T (1997) Differential effects of beta-endorphin and Met- and Leu-enkephalin on steroid hormone-induced lordosis in ovariectomized female rats. Pharmacol Biochem Behav 58:837-842.

Trafton JA, Abbadie C, Marek K, Basbaum AI (2000) Postsynaptic signaling via the $\mu$-opioid receptor: responses of dorsal horn neurons to exogenous opioids and noxious stimulation. J Neurosci 20:8578-8584.

Von Zastrow M, Keith Jr DE, Evans CJ (1993) Agonist-induced state of the delta-opioid receptor that discriminates between opioid peptides and opiate alkaloids. Mol Pharmacol 44:166-172.

Wiesner JB, Moss RL (1984) Beta-endorphin suppression of lordosis behavior in female rats; lack of effect of peripherally-administered naloxone. Life Sci 34:1455-1462.

Wiesner JB, Moss RL (1986) Behavioral specificity of beta-endorphin suppression of sexual behavior: differential receptor antagonism. Pharmacol Biochem Behav 24:1235-1239.

Zadina JE, Hackler L, Ge LJ, Kastin AJ (1997) A potent and selective endogenous agonist for the mu-opiate receptor. Nature 386:499-502. 